\title{
BACTERIAL PHAGOCYTOSIS BY MACROPHAGE OF AUTOGENOUS SPLENIC IMPLANT
}

\author{
MARQUES, R. G., ${ }^{1}$ PETROIANU, Y. ${ }^{2}$ and COELHO, J. M. C. de O. ${ }^{3}$ \\ ${ }^{1}$ Departamento de Cirurgia Geral, Universidade do Estado do Rio de Janeiro, \\ Rio de Janeiro, RJ, Brazil \\ ${ }^{2}$ Departamento de Cirurgia, Universidade Federal de Minas Gerais, \\ Belo Horizonte, MG, Brazil \\ ${ }^{3}$ Departamento de Patologia e Laboratórios, Universidade do Estado do Rio de Janeiro, \\ Rio de Janeiro, RJ, Brazil \\ Correspondence to: Ruy Garcia Marques, Rua Clóvis Salgado, 280/104, Recreio, CEP 22795-230, Rio de Janeiro, \\ RJ, e-mail: rmarques@uerj.br \\ Received April 3, 2002 - Accepted September 17, 2002 - Distributed August 31, 2003
}

(With 2 figures)

\begin{abstract}
Autogenous splenic implant seems to be the only alternative for preservation of splenic tissue after total splenectomy. This work was carried out to analyze the morphologic regeneration of autotransplanted splenic tissue in Wistar rats and to determine the bacterial phagocytic function of their macrophages. We utilized an experimental model with thirty-two rats, of both sexes, submitted to total splenectomy combined with autotransplantation in greater omentum of slices of the whole spleen mass. The animals were divided into two groups: I - young rats weighing 100 to $150 \mathrm{~g}$; and II - adult rats weighing 250 to $300 \mathrm{~g}$. Sixteen weeks later animals were intravenously inoculated with a suspension of Escherichia coli AB1157. Twenty minutes after inoculation, the animals were sacrificed and the splenic autotransplants were removed for morphological study. There was regeneration of autotransplanted splenic tissue in all animals. A similar morphological aspect among all animals was observed, with splenic tissue showing red and white pulps, lymphoid follicles, and marginal zone, with a moderate architectural disarrangement. Macrophages containing gram-negative bacterial aggregates as well as macrophages with hemosiderin pigments within the cytoplasm were observed. Blood vessels showed preserved walls, with no signs of vasculitis or thrombosis. The present results suggest that autogenous splenic implants in the greater omentum of the rat acquire the macro- and microscopic architecture of a normal spleen, with reduced dimensions, and preserve bacterial phagocyte function.
\end{abstract}

Key words: spleen, splenectomy, autogenous splenic implant, splenic autotransplant, regeneration, macrophage, bacterial phagocytosis, sepsis.

\section{RESUMO}

\section{Fagocitose bacteriana por macrófago de auto-implante esplênico}

O auto-implante esplênico parece constituir a única alternativa para preservação de tecido esplênico após esplenectomia total. O objetivo deste trabalho foi analisar a regeneração morfológica de tecido esplênico auto-implantado em ratos Wistar e determinar a função fagocitária bacteriana de seus macrófagos. Utilizamos um modelo experimental com 32 ratos, de ambos os sexos, submetidos a esplenectomia total combinada com auto-implante de fatias de toda a massa esplênica no omento maior. Os animais foram divididos em dois grupos: $\mathrm{I}$ - ratos jovens com peso variando entre $100 \mathrm{~g}$ e 150 $\mathrm{g}$; e II - ratos adultos com peso variando entre $250 \mathrm{~g}$ e $300 \mathrm{~g}$. Dezesseis semanas depois, os animais foram inoculados, por via intravenosa, com uma suspensão de Escherichia coli AB1157. Decorridos 
vinte minutos da inoculação, os animais foram mortos e os implantes esplênicos foram removidos para estudo morfológico. Ocorreu regeneração do tecido esplênico auto-implantado em todos os animais. Foi observado aspecto morfológico similar em todos os animais, com presença de polpas vermelhas e brancas, folículos linfóides e zona marginal, com moderado desarranjo arquitetural. Foram observados macrófagos contendo agregados de bactérias gram-negativas, assim como macrófagos contendo pigmentos de hemosiderina, em seu citoplasma. Os vasos sangüíneos apresentaram paredes preservadas, com ausência de sinais de vasculite ou trombose. Nossos resultados sugerem que o implante esplênico autógeno no omento maior do rato adquire a arquitetura macro e microscópica de um baço normal, de menor dimensão, e preserva a função fagocitária bacteriana.

Palavras-chave: baço, esplenectomia, implante esplênico autógeno, auto-implante esplênico, regeneração, macrófago, fagocitose bacteriana, sepse.

\section{INTRODUCTION}

The technical aspects concerning heterotopic splenic autotransplant have been widely reported on the literature. According to most authors, this is a simple procedure not associated with significant complications (Tavassoli et al., 1973; Pabst \& Reilman, 1980; Patel et al., 1981, 1986; Millikan et al., 1982; Moore et al., 1984; Nielsen et al., 1984; Pabst \& Karam, 1986; Thalhamer et al., 1986; Büyükünal et al., 1987; Iinuma et al., 1992; Timens \& Leemans, 1992; Petroianu et al., 1993, 2000; Leemans et al., 1999; Resende \& Petroianu, 2001). A variety of animal models, as well as studies in humans, confirms the regeneration of autotransplanted splenic tissue showing structural attributes similar to those of the normal spleen. (Tavassoli et al., 1973; Pabst \& Reilman, 1980; Patel et al., 1981; Thalhamer et al., 1986; Iinuma et al., 1992; Resende \& Petroianu, 2001).

Experimental studies investigating the immunoprotector effect of autogenous splenic implants are based on animal exposure to several bacterial species, with evaluation of the following factors: bacterial clearance from the bloodstream (Patel et al., 1986; Cooney et al., 1979; Brown et al., 1981; Malangoni et al., 1988), mortality due to the sepsis caused by the microorganisms (Cooney et al., 1979; Schwartz et al., 1978; Livingston et al., 1982; Malangoni et al., 1985), as well as the potential benefits of immunization combined with splenic autotransplantation (Leemans et al., 1999; Cooney et al., 1979).

Various researches carried out on autogenous splenic implants in humans have indicated recovery of some spleen functions through indirect laboratory methods and scintigraphic techniques. Among the preserved functions, the ability to remove colloidal substances, altered erythrocytes, and corpuscular inclusions, such as Howell-Jolly, Heinz, and Pappenheimer from the bloodstream has been observed (Patel et al., 1981; Millikan et al., 1982; Nielsen et al., 1984; Leemans et al., 1999). Other elements that apparently return to normal are antibody production against pneumococci polysaccharides, and the immunoglobulin levels (notably IgM), complement, platelets, and lymphocytes (Patel et al., 1981; Moore et al., 1984; Nielsen et al., 1984; Büyükünal et al., 1987; Iinuma et al., 1992; Petroianu et al., 2000; Leemans et al., 1999; Resende \& Petroianu, 2001).

Splenic autotransplantation seems to be the only alternative for preserving spleen functions when splenectomy is inevitable and maintenance of splenic tissue is not contraindicated. Nevertheless, splenic regeneration does not necessarily imply recovery of the immune function. Up to now no confirmation exists of preserved spleen capacity for bacterial clearance with this procedure. This study aims to verify if the macrophages of autogenous splenic implants phagocyte Escherichia coli in rats.

\section{MATERIAL AND METHODS}

The study was approved by the Ethics Committee on Animal Research of the Laboratory of Experimental Surgery, Medical Sciences School, Rio de Janeiro State University, Brazil. All procedures rigorously followed the current regulation on animal experimentation (Petroianu, 2000).

Thirty-two Wistar rats of both sexes were divided into two groups: I - young rats weighing 100 to $150 \mathrm{~g}$ (5 males and 14 females); and II - adult 
rats weighing 250 to $300 \mathrm{~g}$ ( 8 males and 5 females). The animals were placed in appropriate cages, five to a cage at most, and received rat chow and water ad libitum.

After a 6-hour fast, the animals were submitted to inhalation anesthesia with halothane, abdominal trichotomy, disinfection with iodopovidine, and placement of surgical fields. Total splenectomy was performed by supraumbilical midline laparotomy. The spleen was weighed and transversely cut into five segments, each about $2 \mathrm{~mm}$ thick. The splenic sections were implanted into the greater omentum using continuous 4-0 polyglycolic acid sutures. Stitches were introduced alternately into the omentum and splenic tissue to permit interposition of omental tissue between the splenic slices. Laparorrhaphy was carried out on two planes (peritoneal-aponeurotic plane and skin) using continuous 3-0 polyglycolic acid sutures.

A suspension of Escherichia coli AB1157 containing a bacterial concentration corresponding to $10^{8}$ colony-forming units (CFU) was used.

Sixteen weeks after the beginning of the experiment, the animals were submitted to inhalation anesthesia with halothane, cervical and abdominal trichotomy, and disinfection with iodopovidine. Rats were inoculated with $E$. coli by direct transverse cervicotomy and dissection of the internal jugular vein. Twenty minutes after inoculation, the animals were sacrificed with a halothane overdose and submitted to midline laparotomy. Splenic implants were removed and placed in a solution containing buffered $10 \%$ formalin. The tissue was processed with increasing concentrations of alcohol and xylol, embedded in paraffin, and cut into $4 \mu \mathrm{m}$-thick slices. Slides prepared from these slices were stained with hematoxylin and eosin (HE) and Gram, being analyzed by light microscopy.

\section{RESULTS}

Regeneration of the splenic implants was observed in all animals. In the comparison between young and adult animals, the adults showed a larger mean implanted and regenerated mass.

Microscopic examination revealed a similar morphological aspect among all animals, with presence of red and white pulps in a moderate architectural disarrangement. Although a reduction of white pulp was observed, lymphoid follicles were present. A decrease of the marginal zone was also observed, and germinative centres were not found. Macrophages containing bacterial aggregates were verified, as well as macrophages with pigments of hemosiderin inside the cytoplasm. Blood vessels showed preserved walls, with no signs of vasculitis or thrombosis.

Fig. 1 shows the microscopic morphology of a macrophage of a regenerated splenic autotransplant, with bacterial aggregates within its cytoplasm, stained with hematoxylin and eosin, 1,000 x amplified. Stained with Gram, and also amplified 1,000 x were macrophages with gram-negative bacterial aggregates around their nucleus (Fig. 2).

\section{DISCUSSION}

Based on the notion that the regeneration of autogenous splenic implants begins in a centripetal way, from the periphery to the implant center, it was observed that all implants presented splenic regeneration, with presence of red and white pulps, lymphoid follicles, and a marginal zone (Tavassoli et al., 1973; Iinuma et al., 1992).

The importance of spleen in removing encapsulated bacteria has been intensively studied and is now accepted (Timens \& Leemans, 1992; Leemans et al., 1999; Brown et al., 1981). It has also been observed that the presence of splenic tissue remnants in situ allows for more efficacy in clearing Escherichia coli from the bloodstream in rats and rabbits (Silva, 2000; Scher et al., 1982). However, the phagocytosis of nonencapsulated gram-negative bacteria by autogenous splenic implants has not been evaluated.

Escherichia coli was used due to the wide knowledge available about it and also because it is part of the normal intestinal flora in humans. It is important to point out that this bacteria is responsible for about $12 \%$ of overwhelming postsplenectomy infection. Gram-negative bacteria are the main etiological agents of infections in elderly splenectomized patients debilitated by chronic diseases (Singer, 1973; Hansen \& Singer, 2001).

The presence of gram-negative bacterial aggregates around macrophage nuclei in splenic autotransplant parenchyma proves the preservation of the bacterial phagocytic function of these main body defence cells. The presence of hemosiderin pigment inside the macrophages also indicates that these cells phagocytize blood elements in the physiologic destruction of altered hematic cells, especially due to their senescence. 


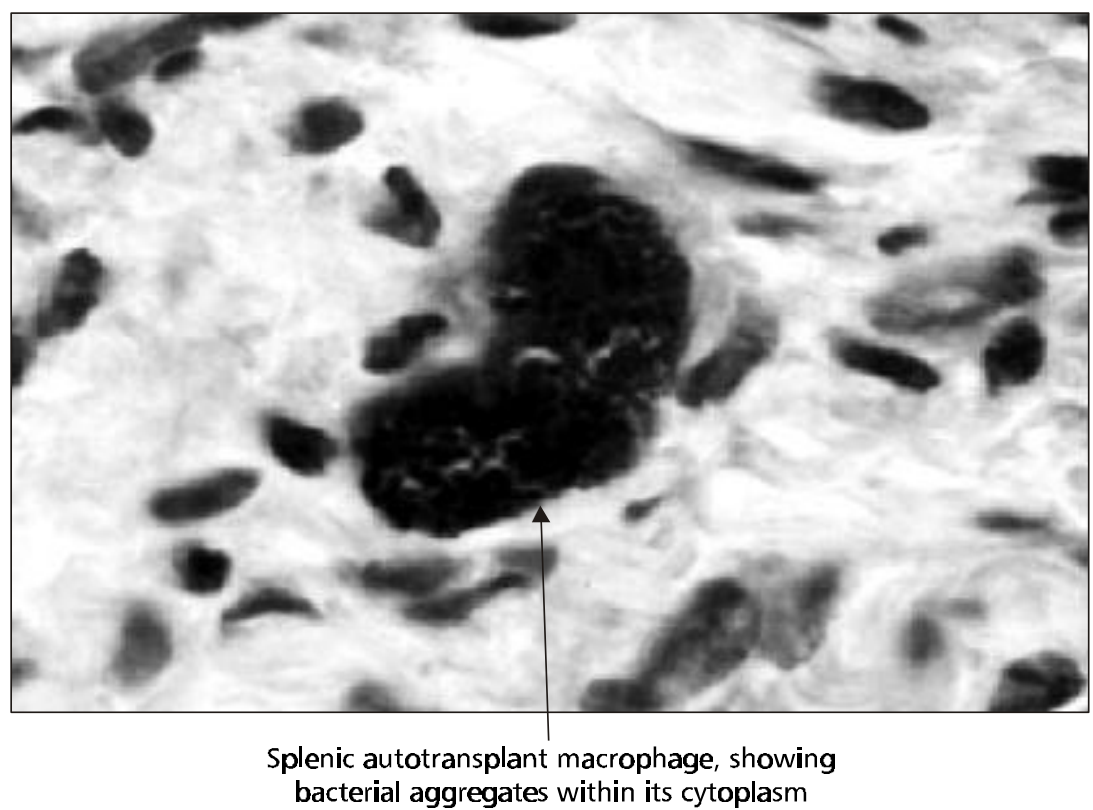

Fig. 1 - Microscopic morphology of a splenic autotransplant macrophage, with bacterial aggregates within its cytoplasm $(\mathrm{HE}-1.000 \mathrm{x})$

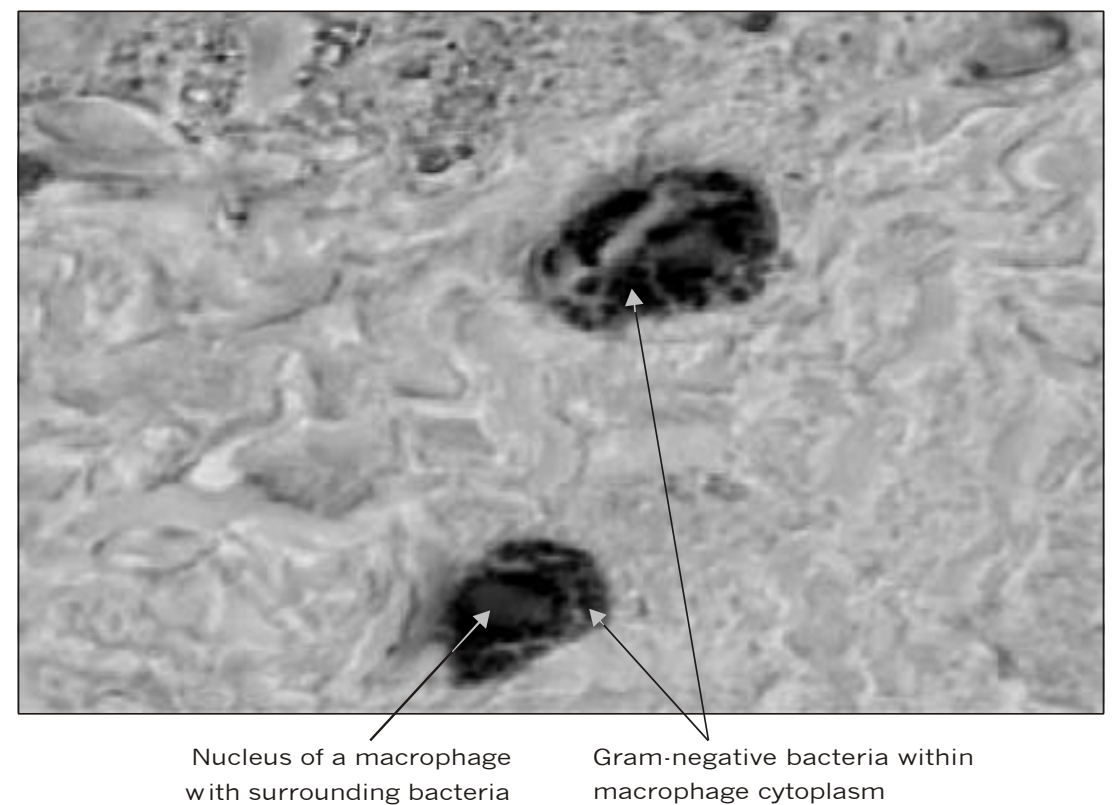

Fig. 2 - Microscopic morphology of gram-negative bacterial aggregates around the nucleus of splenic autotransplant macrophages $($ gram $-1.000 \mathrm{x})$. 
In conclusion, splenic autotransplantation provides protection from Escherichia coli sepsis in rats, preserving spleen phagocytic function. Additional researches involving other animal species, and other bacteria as well, are needed to verify if these autogenous splenic implants can supply enough immunoprotection to reduce the incidence of overwhelming postsplenectomy infection.

\section{REFERENCES}

BROWN, E. J., HOSEA, S. W. \& FRANK, M. M., 1981, The role of the spleen in experimental pneumococccal bacteremia. J. Clin. Invest., 67(4): 975-982.

BÜYÜKÜNAL, C., DANISMEND, N. \& YEKER, D., 1987, Spleen-saving procedures in pediatric splenic trauma. $B r$. J. Surg., 74(5): 350-352.

COONEY, D. R., DEARTH, J. C., SWANSON, S. E., DEWANJEE, M. K. \& TELANDER, R. L., 1979, Relative merits of partial splenectomy, splenic reimplantation, and immunization in preventing postsplenectomy infection. Surgery, 86(10): 561-569.

HANSEN, K. \& SINGER, D.B., 2001, Asplenic-hyposplenic overwhelming sepsis: Postsplenectomy sepsis revisited. Pediatr. Devel. Pathol., 4(2): 105-121.

IINUMA, H., OKINAGA, K., SATO, S., TOMIOKA, M. \& MATSUMOTO, K., 1992, Optimal site and amount of splenic tissue for autotransplantation. J. Surg. Res., 53(2): 109-116.

LEEMANS, R., MANSON, W., SNIJDER, J. A. M., HAUWTHE, T. \& KLASEN, H. J., 1999, Immune response capacity after human splenic autotransplantation. Ann. Surg., 229(2): 279-285.

LIVINGSTON, C. D., LEVINE, B. A. \& SIRINEK, K. R., 1982, Preservation of splenic tissue prevents postsplenectomy pulmonary sepsis following bacterial challenge. J. Surg. Res., 33(4): 356-361.

MALANGONI, M. A., DAWES, L. G., DROEGE, E. A., RAO, A. S., COLlIER, D. \& ALMAGRO, U. A., 1985, Splenic phagocytic function after partial splenectomy and splenic autotransplantation. Arch. Surg., 120(3): 275-278.

MALANGONI, M. A., EVERS, B. M., PEYTON, J. C. \& WELLHAUSEN, S. R., 1988, Reticuloendothelial clearance and splenic mononuclear cell populations after resection and autotransplantation. Am. J. Surg., 155(2): 298-302.

MILLIKAN, J. S., MOORE, E. E., MOORE, G. E. \& STEVENS, R. E., 1982, Alternatives to splenectomy in adults after trauma. Am. J. Surg., 144(12): 711-716.

MOORE, F. A., MOORE, E. E., MOORE, G. E. \& MILLIKAN, J. S., 1984, Risk of splenic salvage after trauma. Analysis of 200 adults. Am. J. Surg., 148(4): 800-805.

NIELSEN, J. L., SAKSO, P., SORENSEN, F. H. \& HANSEN, H. H., 1984, Demonstration of splenic functions following splenectomy and autologous spleen implantation. Acta Chir. Scand., 150(4): 469-473.
PABST, R. \& KAMRAN, D., 1986, Autotransplantation of splenic tissue. J. Pediatr. Surg., 21(2): 120-124.

PABST, R. \& REILMANN, H., 1980, Regeneration of heterotopically transplanted autologous splenic tissue. Cell Tissue Res., 209(1): 137-143.

PATEL, J. M., WILLIAMS, J. S., NAIM, J. O. \& HINSHAW, J. R., 1986, The effect of site and technique of splenic tissue reimplantation on pneumococcal clearance from the blood. J. Pediatr. Surg., 21(10): 877-880.

PATEL, J. M., WILLIAMS, J. S., SHMIGEL, B. \& HINSHAW, J. R., 1981, Preservation of splenic function by autotransplantation of traumatized spleen in man. Surgery, 90(10): 683-688.

PETROIANU A., SIMAL C. J. R. \& BARBOSA, A. J. A., 1993, Assessment of phagocytic function in remnants of subtotal splenectomy and in autologous spleen implantation. Med. Sci. Res., 21(10): 715-717.

PETROIANU, A., 2000, Pesquisa experimental. In: A. Petroianu (ed.), Ética Moral e Deontologia Médica. Editora Guanabara Koogan, Rio de Janeiro, RJ, Brazil, pp. 185-190.

PETROIANU, A., VIDIGAL, F. M., COSTA, V. C. \& OLIVEIRA, S. C., 2000, Splenic autotransplantation in Gaucher's disease. Dig. Surg., 17(2): 181-183.

RESENDE, V. \& PETROIANU, A., 2001, Estudo funcional tardio do auto-implante esplênico após trauma complexo do baço humano. Rev. Col. Bras. Cir., 28(3): 165-170.

SCHER, K. S., WROCZYNSKI, F. \& COIL, J. A., 1982, The effect of splenectomy on gram-negative bacteremia. $J$. Trauma., 22(5): 407-409.

SCHWARTZ, A. D., GOLDTHORN, J. F., WINKELSTEIN, J. A. \& SWIFT, A. J., 1978, Lack of protective effect of autotransplanted splenic tissue to pneumococcal challenge. Blood, 51(3): 475-478.

SILVA, R. G., 2000, Fagocitose da Escherichia coli pelo sistema mononuclear fagocitário, após esplenectomias subtotal, parcial e total, em rato. Tese de Doutorado, Universidade Federal de Minas Gerais, Belo Horizonte, MG, Brazil.

SINGER, D., 1973, Postsplenectomy sepsis. Perspect. Pediatr. Pathol., 1: 285-311.

TAVASSOLI, M., RATZAN, R. J. \& CROSBY, W. H., 1973, Studies on regeneration of heterotopic splenic autotransplants. Blood, 41(5): 701-709.

THALHAMER, J., LEITNER, W., KURAZ, M. E., LIAUNIGG, A., SEIFRIEDSBERGER, M. \& BERGMANN, E. S., 1992, Immunoarchitecture and specific functions of splenic autotransplants at different implantation sites. Eur. Surg. Res., 24(1): 22-36.

THALHAMER, J., PIMPL, W. \& PATTERMANN, M., 1986, The role of the spleen and splenic autotransplants in clearing experimental bacteremia caused by the gram-negative bacterium E. coli. Res. Exp. Med., 186(3): 229-238.

TIMENS, W. \& LEEMANS, R., 1992, Splenic autotransplantation and the immune system. Adequate testing required for evaluation of effect. Ann. Surg. 215(3): 256-260. 